\title{
Inequalities and capital accumulation in China
}

\author{
Desigualdades e acumulação de capital na China
}

\author{
ISABELA NOGUEIRA* \\ JOÃO VICTOR GUIMARÃES** \\ JOÃO PEDRO BRAGA***,
}

RESUMO: Esse artigo contribui para o debate sobre distribuição de renda e riqueza na China ao analisar as principais características do padrão de acumulação chinês que determinam sua dinâmica distributiva em uma perspectiva comparada. Depois de um período de rápido crescimento das desigualdades, acompanhado por redução abissal da pobreza e melhora nas condições de vida de todos os decis da distribuição, as desigualdades se estabilizaram na China desde meados dos anos 2000. Globalmente, a China se encontra hoje em uma situação distributiva pior do que a média da Europa Ocidental ou Japão, mas mais igualitária do que Estados Unidos e muito distante dos limites extremos da má distribuição como Brasil, Índia, África do Sul e Oriente Médio. Neste artigo, nós escrutinamos três características do regime de acumulação na China que arrefecem a tendência concentradora do capital naquele país: 1 . o processo de financeirização com características chinesas, 2. a estratégica fatia da propriedade estatal na economia, 3. sua trajetória na questão agrária.

PALAVRAS-CHAVE: Desigualdades; China; acumulação de capital; financeirização; propriedade estatal; questão agrária.

ABSTRACT: This article contributes to the debate on income and wealth distribution in China by analyzing the main characteristics of the Chinese accumulation pattern that determine its distributive dynamics in a comparative perspective. After a period of rapid growth of inequalities, coupled with improved living conditions for all distribution deciles, inequalities

\footnotetext{
*Professora Adjunta do Instituto de Economia e do Programa de Pós-Graduação em Economia Política Internacional da Universidade Federal do Rio de Janeiro - IE/PEPI/UFRJ, Rio de Janeiro/RJ, Brasil. Pesquisadora do CNPq. E-mail: isabela.nogueira@ie.ufrj.br. ORCID: 0000-0001-8223-7906.

* Mestrando do Instituto de Economia e Programa de Pós-Graduação em Economia Política Internacional da Universidade Federal do Rio de Janeiro - IE/PEPI/UFRJ, Rio de Janeiro/RJ, Brasil. E-mail: jvictorguimaraes@ufrj.br ORCID: 0000-0003-3269-6105.

***Estudante de Graduação do Instituto de Economia da Universidade Federal do Rio de Janeiro - IE/ UFRJ, Rio de Janeiro/RJ, Brasil. E-mail: jpedrolbraga@gmail.com. ORCID: 0000-0002-4599-1712. Submitted: 27/March/2018; Approved: 4/December/2018.

+ The authors would like to thank Celia Lessa Kerstenetzky, two anonymous referees and other members of the Center for Studies on Inequality and Development (CEDE) for very helpful discussion and suggestions. They are all researchers at LabChina (China's Political Economy Lab).
} 
have stabilized in China since the mid-2000s. Globally, China is today in a distributive pattern worse than Western Europe or Japan, but it is more egalitarian than the United States and far from the world inequality frontier defined by Brazil, India, South Africa and the Middle East. In this article, we scrutinize three characteristics of the regime of accumulation in China that mitigate the capital-concentrating tendency: 1. the financialization process with Chinese characteristics, 2. the strategic share of State ownership in the economy, 3. its trajectory over the agrarian question.

KEYWORDS: Inequalities; China; capital accumulation; financialization; state ownership; agrarian question.

JEL Classification: O10; O53; D30; P16.

\section{INTRODUCTION}

Inequalities have become a hot topic globally for both academic and very concrete reasons. Not only data availability now makes international comparisons much more feasible, but also global imbalances associated with growing wealth and income gaps are popping up into everyone's eyes. From Trump to Brexit, there is a growing interpretation that different political phenomena are associated with exacerbated inequalities. As the second largest economy in the world, China is going through rapid changes in its social formation, in this sense its distributional dynamics is among the most relevant cases to be studied in detail.

Drawing on his success with Capital in the Twenty-First Century, Thomas Piketty launched a major database that now makes international comparisons possible and clear. The World Income and Wealth Database (WID.world) combines several data sources - national accounts, surveys, wealth rankings and income tax data covering high earners, thus providing systematic estimates of the level and structure of several countries' income and wealth profile. The inequality series are homogenous and can be used to compare inequalities across countries in a consistent way (Alvaredo et al., 2018). Up to now, scholars had to rely on household surveys based upon self-reported information, which underestimates inequality. In the case of China, this is the first time that tax data on high earners are used to estimate income and wealth distribution.

In brief, in their paper on China, Piketty, Li and Zucman (2017) conclude that inequality levels in China are now worse than Western Europe or Japan, but more egalitarian than the United States and far from world inequality frontier defined by Brazil, India, South Africa and the Middle East. Their contribution is mainly statistical, although they leave important insights of how the property structure, with a large share of public property, might contribute to mitigate the rise of inequality.

In this article, we revise previous works based on The World Income and Wealth Database and scrutinize which characteristics of the Chinese capital accumulation process led to such distributional profile. We rely loosely on the regulation theory approach (Aglietta, 1976) in order to shed light into selected aspects of 
China's accumulation process. According to the French school of regulation theory, a regime of accumulation involves social and economic regularities, such as how production is organized and how workers relate to the means of production; the composition of social demand; the distributive pattern; and the articulation of noncapitalist forms. A regime of accumulation is, by its turn, sustained and guided by a set of social institutions called mode of regulation, including the monetary and financial regime; the form of organization of the State; and the international regime (Paulani, 2009).

We argue that contrary to the current finance-led regime of accumulation which prevails globally, China's mode of regulation has three major distinctive characteristics: 1 . a financialization with Chinese characteristics, 2. a large and strategic share of State ownership, and 3. an egalitarian agrarian structure. Combined, these three characteristics tend to mitigate capital concentration in China if compared to other traditional finance-led regime of accumulation. In the next section, we review China's inequality dynamics both domestically and in a comparative perspective. The subsequent three sections are dedicated, each of them, to a selected aspect of Chinese mode of regulation that determines its regime of accumulation and distributional dynamics - financialization with Chinese characteristics, State ownership and the agrarian structure. The last section summarizes our main conclusions.

\section{INEQUALITIES IN CHINA AND IN COMPARATIVE PERSPECTIVE}

There is a straightforward narrative over the trajectory of inequality in China since reforms started in 1978. China went from a highly egalitarian country, similar to Nordic levels (Gini Index of 0.27 in 1983, when it reached its lowest level), to a distributional profile closer to the United States in the mid-2000. According to the Communist Party of China (CCP), these levels could cause disruptions to a "harmonious society". Indeed, the 2000's were marked in China by intense contestation in the form of large-scale strikes, workers' suicides inside factories and peasants' unrests (Pun, 2016). Since then, several policies were put into place to curb inequalities and the Gini Index declined slightly to 0.46 in 2016 (Graph 1).

A vast literature has already identified different causes and has given different emphasis on the mechanisms that are behind growing inequalities in China. These factors include explosive income gap between rural and urban areas, structural heterogeneity between regions and sectors, privatization of state-owned companies and public housing, wage differentials in urban areas and the emergence of a capitalist class simultaneously with the surge of a highly exploited labor class - including the precarious living conditions and low wages of migrant workers (Pun, 2016; Li, Sato and Sicular, 2013; Medeiros, 2012; Medeiros e Nogueira, 2011; Khan and Riskin, 2008).

The literature on inequalities in China also shares a second consensus: inequality increased simultaneously with the sensitive rise in the living conditions of the poorest. 


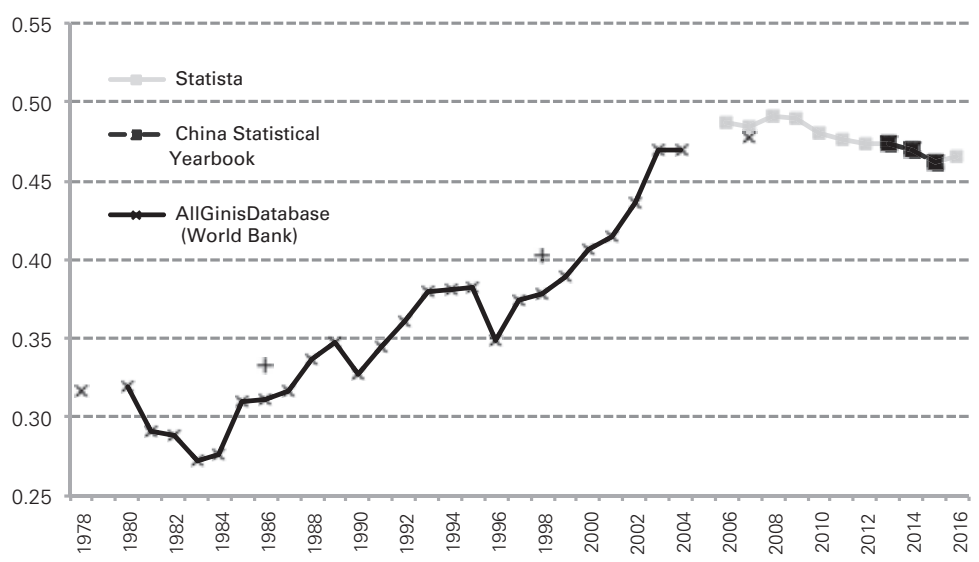

Sources: National Bureau of Statistics (China) and The World Bank.

This trajectory contrasts heavily to the United States, where the living conditions of the poor has stagnated over the past 40 years or has gotten worst in the past decade, while in China the poorest decile of distribution saw a significant improvement in their living conditions. From 1978 to 2015 the average real income per adult in the United States was virtually stagnated among the poorest half of the population, with a growth rate of $0.3 \%$. In China, for the same group in the same period, growth rate was $4.7 \%$. This is half of the rate of the richest $1 \%$ of national income, but still a significant change in terms of living conditions. Taking a shorter and more recent period, the difference among the two countries is even more pronounced. From 2000-2015, among the poorest $50 \%$ of the population, the average growth rate of real income per adult was $7.5 \%$ in China, against a drop of $-0.7 \%$ in the United States (Graph 2).

How are Chinese inequalities nowadays compared to other countries in terms of their level and structure? This is where the World Income and Wealth Database (WID. world) brings a fundamental contribution. The first remarkable observation is that Chinese distribution profile has nothing to do with the "extreme" cases that have characterized the social formation of Brazil, India, Middle East and South Africa - the group of countries with the highest income concentration in the world. In other terms, despite rapid growth, China does not belong to the "world inequality frontier" (Alvaredo et al., 2018). Not only this makes China a remarkable case among the BRICS countries but it unnaturalizes any distributional tendency. That is to say - neither big emerging countries naturally tend to be very unequal, nor fast growing countries will necessarily watch an absurd growth in inequality. And finally, not all transitions from a central planned economy to a market economy lead to a similar distributional outcome as comparative studies on China and Soviet Union/Russia show.

China's distributional profile ${ }^{1}$ is nowadays comparable to developed countries

\footnotetext{
${ }^{1}$ Hong Kong and Macao are excluded from all macro and micro data. This may have lead to an underestimation of the rise of inequality (Piketty, Li and Zucman, 2017, p. 33).
} 


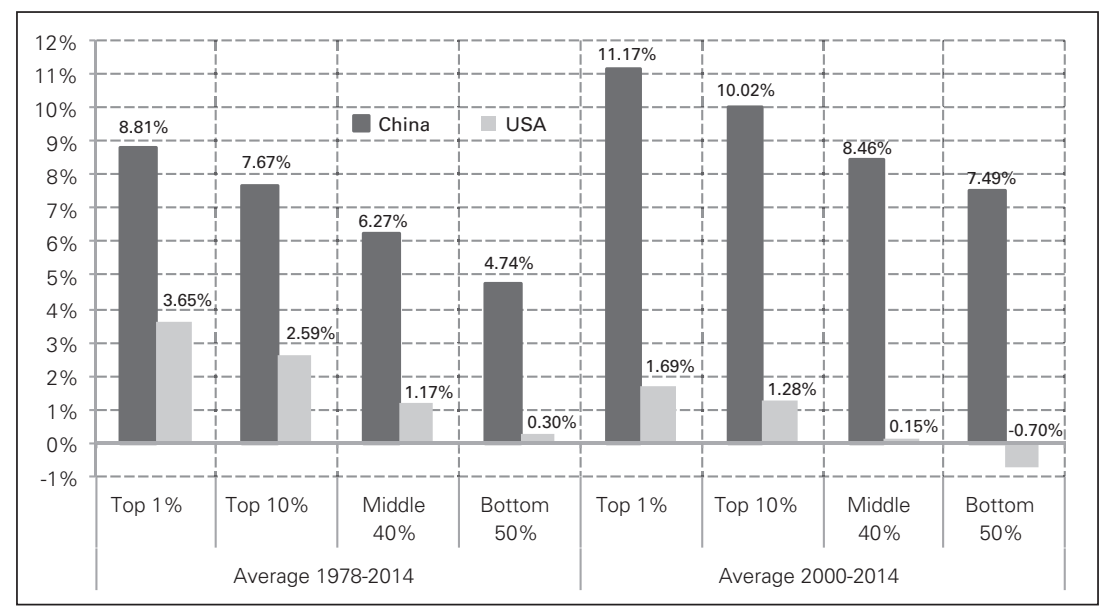

Source: World Wealth \& Income Database (WID.world).

and lays somewhere between Western Europe and North America - more egalitarian than the latter and less than Europe's development model. And contrary to developed nations, inequality in China seems to have stabilized since the 2008 financial crises - or is tending towards some reduction. When looking to evolution of the top $10 \%$ earners in a nation's income, Chinese top $10 \%$ share reached $41 \%$ in 2016, getting close to that of the United States-Canada (47\%) and higher than Western Europe (37\%). As mentioned before, Chinese inequality levels are substantially lower than its emerging countries' counterparts, such as Sub-Saharan Africa (54\%), India (55\%), Brazil (55\%) or Middle East (64\%) (Alvaredo et al., 2018).

Graph 3: Top 10\% National Income Share (Pre-Tax) in Selected Countries, 1978-2015

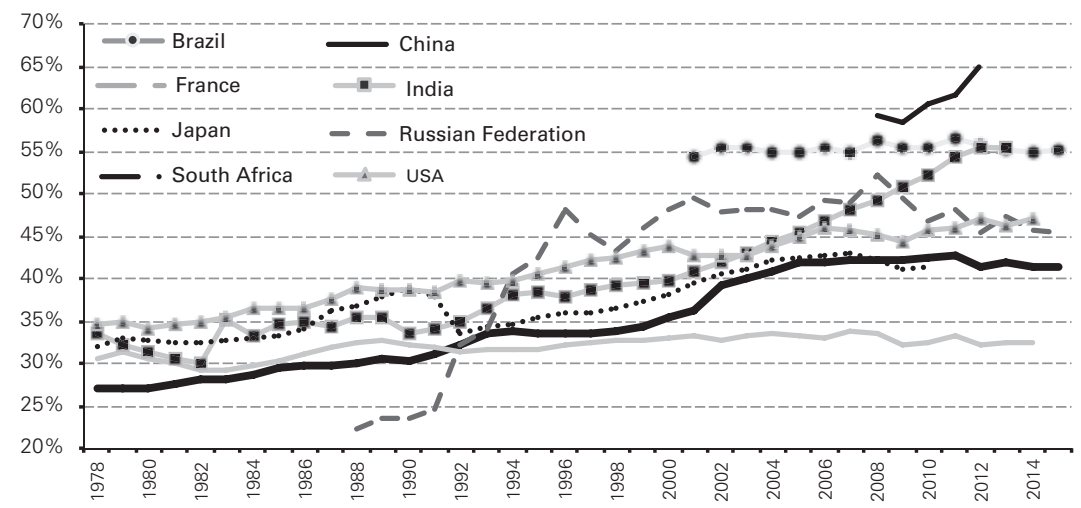

Source: World Wealth \& Income Database (WID.world). 
In terms of the top $1 \%$, distribution in China takes distance from the "new working rich" category that prevails in the United States (Boyer, 2010), with the remuneration of top executives increasing dramatically. In 2015, the top $1 \%$ in China had 13,9\% of national income, equivalent to the United Kingdom $(13,9 \%$ in 2014). This is worse than South Korea (12,2\% in 2012), Japan (10,4\% in 2010) or Norway (7,8\% in 2011) but much better than South Africa (19,2\% in 2012), the United States (20,2\% in 2014), Russia (20,2\% in 2015), India (21,7\% in 2013$)$ or Brazil $(27,8 \% \text { in } 2015)^{2}$.

Graph 4: Top 1\% National Income Share (Pre-Tax) in Selected Countries, 1978-2015

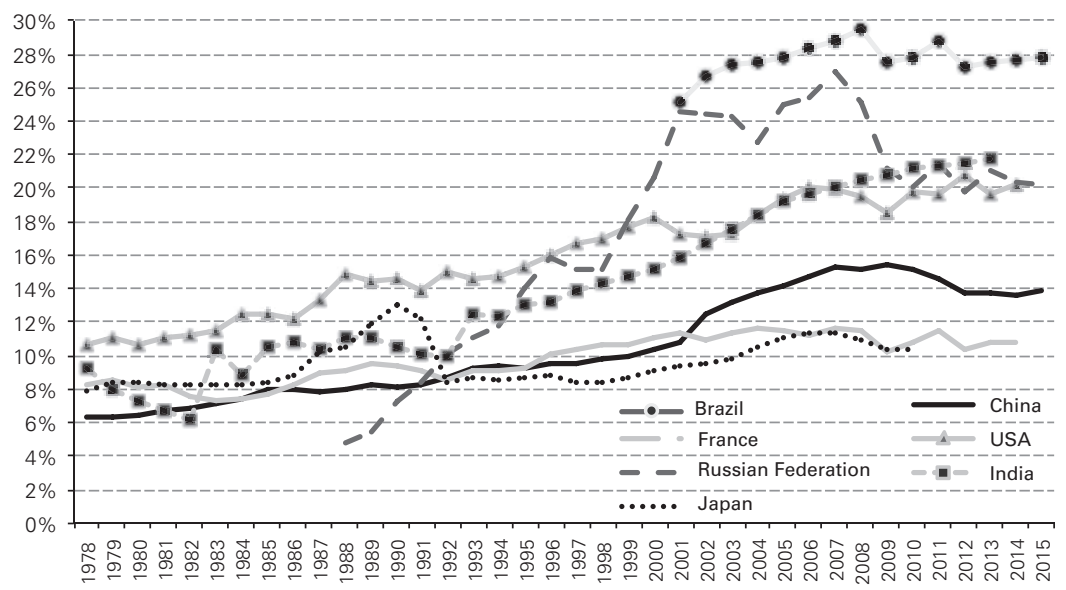

Source: World Wealth \& Income Database (WID.world).

Although the statistical contribution brought by the WID.world database is remarkable, several qualitative questions remain untouched by their group of researchers. The diversity of trends observed shows that income inequality dynamics are shaped by a variety of national, institutional and political contexts (Alvaredo et al., 2018). This is exactly where this paper aims to contribute. From a capital accumulation perspective, which characteristics of the Chinese regime of accumulation make it a moderate case in terms of inequalities? Especially if one considers the dimension of the Chinese economy and the velocity of its societal changes, it is quite remarkable that Chinese inequality pattern is substantially different from other BRICS countries. Some institutional breaks are in place curbing the concentrating-tendency of capital. The main differences, we argue, are to be found in its financial regime, in the form of organization of the State, and in the institutions that guide Chinese agrarian change.

\footnotetext{
${ }^{2}$ Last year available for each country. All data from World Wealth and Income Database. Available at: $<$ https://wid.world/http://wid.world/>. Last access in February $2^{\text {nd }} 2018$.
} 


\section{HOLDING INEQUALITIES BACK I: FINANCIALIZATION WITH CHINESE CHARACTERISTICS}

A major characteristic that distinguishes Chinese regime of accumulation to other central or peripheral economies is its relative autonomy in relation to the financialization process under dollar's hegemony. The finance-led regime of accumulation which has defined capitalist reproduction from the United States to Europe, encompassing also Latin America and Africa since the neoliberal age started in the 1980s, does not penetrate the Chinese economy with the same intensity. Largely, this is due to a financial system mainly state-owned, with a huge share of the banking system under the so-called "Big Five" state-owned commercial banks (Industrial and Commercial Bank of China, Bank of China, China Construction Bank, Agricultural Bank of China and Bank of Communications). State-owned commercial banks are responsible for around $80 \%$ of all national credit mediation (Vermeiren and Dierckx, 2012). Besides commercial banks, the long-term financing needs are also met by three development banks obviously under the State Council (China Development Bank, Exim Bank of China and Agricultural Development Bank of China) and the newly launched international development banks under Chinese tutorage (such as the Asian Infrastructure and Development Bank and the New Development Bank for the BRICS).

Besides a mainly state-owned banking system, a second pillar of Chinese financialization is shaped by its extensive capital controls. Due to stringent regulations on cross-border capital flows imposed by the government, short-term speculation is heavily restricted, and China has been shielded from external economic and financial shocks, as the limited effects of the East Asian financial crisis and of the US subprime crisis have shown. Current restrictions exist mainly for cross-border portfolio investment, debt financing and outward direct investment. For instance, domestic non-financial enterprises are strictly prohibited from extending any external loans. In the securities markets, foreign investors are not allowed to buy renminbi-denominated A shares, bonds or other market instruments, unless they have Qualified Foreign Institutional Investor (QFII) quota. There are also heavy controls on certain phases of foreign exchange transactions, such as restrictions on cross-border fund remittance and repatriation and $\mathrm{RMB} /$ foreign currency exchange related to capital account transactions. Also, outward direct investment by domestic entities needs to be approved by the State Administration of Foreign Exchange (SAFE), the Ministry of Finance and the National Development and Reform Commission (Huang et al., 2011, p. 29-30).

Such a system of extensive capital controls and administrated and low interest rates has facilitated lending and avoided upward pressures on the exchange rate. As Vermeiren and Dierckx (2012, p. 1654) summarize, "by clearly contradicting the interests of transnational capital [...], stringent capital account regulations have effectively prevented the penetration of the Chinese financial system by transnational corporations and foreign investors". Capital controls and low interest rates are at the core of the State's development strategy. They have been crucial pillars 
of the State's arsenal for engineering and channeling its massive domestic investment and for giving birth to the so-called investment-led growth regime. Stateowned banks have funded investments by SOEs at very low interest rates (Panitch and Gindin, 2013; Vermeiren and Dierckx, 2012).

We are dealing, therefore, with a financialization with Chinese characteristics: captained by a massive state-owned banking system and under strict capital control. Contrary to financial globalization under the US dollar, Chinese financialization has not displaced productive firms from their original core activities, therefore they do not depend directly on the financial markets for the largest share of their revenue. In the criticism of François Chesnais (1994) to the "mondialisation du capital", large productive enterprises in Western countries have been avoiding the risks of manufacturing or industrial innovation and turned to open markets to obtain finance. In the same way, Chinese financialization did not come in order to compensate the fall of wages in national income through household's indebtedness - and, therefore, to assure consumption even without payroll, as Costas Lapavitsas (2009) has highlighted in the case of "financial expropriation" taking place in the United States and in several parts of peripheral Europe. Specially in the United States, enormous expansion of mortgage-lending, including to the poorest layers of the working class, and the retreat of public provision from housing, pensions and education opened avenues for extraction of financial profits directly out of personal income (Costas Lapavitsas, 2009). Finally, financialization in China has not affected the autonomy of macroeconomic policies as in the case of Brazil, where the growing political power of financial markets and related elites has given them the control over key State apparatus (Bruno et al., 2011). Nothing similar has ever happened in China.

This is not to say that the Chinese economy has not been through a fast expansion of financialization in the past decades. Financialization with Chinese characteristics mobilized and channeled domestic resources via the financial system for major infrastructure and urbanization projects and initiatives. And at the same time, it has opened channels for the penetration of private capitalists in the financial and speculative circuits, which is in the cause of the current real estate bubble and heavy speculation on stock exchanges, as Graph 5 shows. Nevertheless, Chinese financialization has taken place with an intense limitation on the connections of the domestic financial system with international players. This does not mean that the structure of the financial system is entirely under the control of the national authorities, as shown by the huge expansion of shadow banking-which serves private companies with limited access to the State banking system (Cintra and Silva, 2015). However, Chinese financialization is heavily regulated in relation to foreign control over the national system. 
Graph 5: Shanghai Stock Exchange by Market Capitalization,

Jan. 2013 - Sep. 2018 (USD millions)

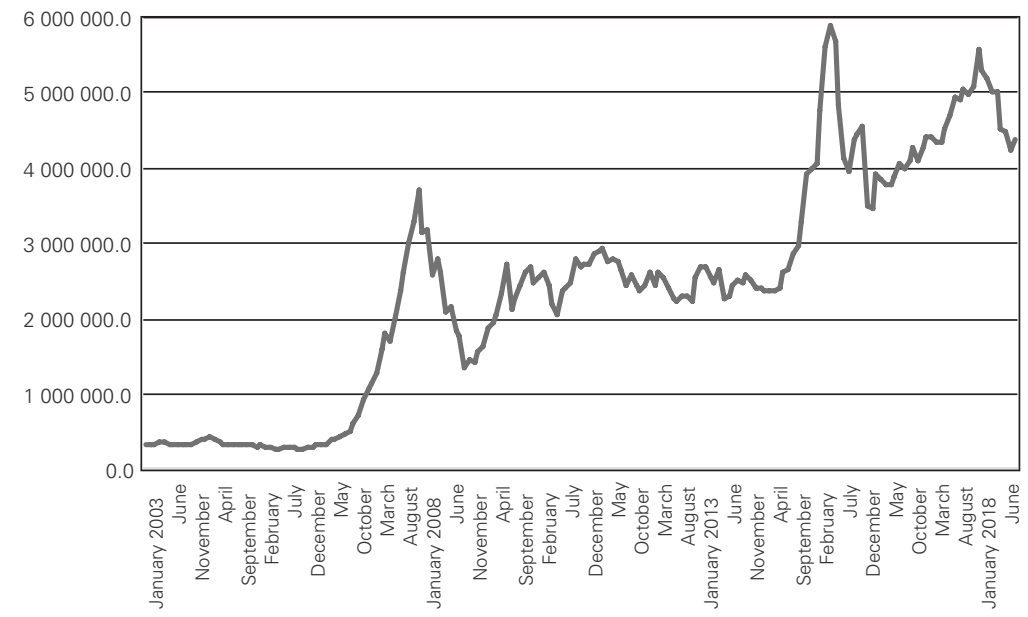

Source: World Federation of Exchange.

This process of financialization essentially controlled by the State arose in the mid-1990s and gained spectacular impetus in the mid-2000s. While the State maintains tight control over the capital account, private capitalists have penetrated China's financial circuits in two ways: (i) shareholding in State corporations through direct purchase of shares, participation in financial holding companies, investment funds and insurance companies; and (ii) via the tripod infrastructure, real estate speculation and new financial platforms such as so-called structured special purpose vehicles (SPV).

The financialization of state-owned enterprises has led to what Wang (2015) calls the "shareholding State". Virtually all major state-owned enterprises have been transformed into publicly traded corporations and have undergone an accelerated process of securitization in the last decade, mainly as a way to raise capital to finance infrastructure projects inside and outside China. The goal is to broaden access to financial and corporate governance instruments and to pressure managers and boards of directors to deliver results without reducing State control (Wang, 2015). In other words, this strategy aims to make SOEs competitive internationally with abundant access to capital without losing the strategic orientation of the State.

Local governments, for their part, have made aggressive use of risky financial products to finance urbanization, through a type of special purpose vehicle called local financing platform (LFP). In 2013, more than 7,000 LFPs were accounted for, with loans representing $40 \%$ of local government debt (Wang, 2015). LFPs use different State assets as collateral-from leasing sliced public services to state-owned enterprises, tax revenues and, above all, mortgaged land. These structured products are then repackaged into securitized products sold by banks to rich customers.

The emergence of a financialized State at the local and central levels, however, was accompanied by the emergence of capitalists who withdraw increasing slic- 
es of their earnings from different types of financial activities. Together with outside interests, they are the ones pushing for the opening of China's capital account. In March 2017, during the $5^{\text {th }}$ session of the $12^{\text {th }}$ National People's Congress, executives from the financial and civil construction sectors openly criticized capital controls as instruments that hinder Chinese acquisitions abroad ${ }^{3}$. So far, Chinese financialization has maintained autonomy in relation to the power of the dollar precisely because of capital controls. However, internal and external pressures are strong, and China's expressive capital outflows in 2016 show its vulnerability to unregulated speculative movements. In 2016, during a limited liberalization attempt, China lost almost half a trillion dollars in international reserves (precisely US\$ 443 billion), bringing total reserves down to below US\$ 3 trillion for the first time since 2011 (Chen, 2017).

Financialization with Chinese characteristics is centered on the attempt to create a monetary system less dependent on the dollar and based on multipolar institutions under Chinese control or influence (Aglietta and Bai, 2017). We are not talking about the existence of a structured plan to replace the dollar as the hegemonic currency of the system, but rather of attempts to expand China's capital maneuvering space around the world with less subordination to the power of the US currency. This strategy is taking place in two ways. First through the consolidation and expansion of development banks as ultimate lenders (such as the Asian Infrastructure Investment Bank), expecting that the infrastructure funded by such banks will be a dynamic engine of global growth - the "Belt and Road Initiative" is the strategy that ties all the tips. And secondly, through the expansion of the international use of the renminbi in commercial transactions, especially for oil. For instance, China is planning to set up future oil markets in its own currency, therefore being traded in yuan, not dollar, on the Shanghai International Energy Exchange (INE). This is a clear challenge to petrodollars, one of the elements that sustain the dollar as the monetary standard of the international system (Escobar, 2017).

In sum, financialization with Chinese characteristics makes China's regime of accumulation very different from the prevailing one in most of developing and developed worlds. There is no process of displacement of productive capacity, no growing influence of financial markets over macroeconomic policy-making and neither declining wages in productive sectors. Captained by a massive stateowned system and under strict capital control, financialization with Chinese characteristics led to massive investments in infrastructure. It has also been a pillar of its industrial, innovation and national-champions policies, as we will explore in the next section.

\footnotetext{
${ }^{3}$ China's capital control trigger a backlash after scrapped deals. Bloomberg News, March $7^{\text {th }} 2017$. Available at: <https://www.bloomberg.com/news/articles/2017-03-07/china-s-capital-controls-trigger-abacklash-after-deals-thwarted>. Last Access in March 12 2018.
} 


\section{HOLDING INEQUALITIES BACK II: STATE OWNERSHIP}

As the history of Western countries shows, the structure of national property has huge implications for economic development and for inequalities. Public wealth has been declining fast and has become very small or even negative in Western countries (Graph 6) given the privatization process of former StateOwned Enterprises (SOEs) and the growth in public debt exceeding public assets. The small size of public property affects the State's ability to conduct industrial and regional development policies and, therefore, directly weakens the State's capacity to promote structural change. Structural change is necessarily a complex process with multiple determinants, including productivity and demand regimes and the underlying institutional framework. SOEs are in a key position to direct State influences over these multiple determinants, especially if they are located in the nodes of capital accumulation, such as in capital-intensive large scale upstream industries.

The share of public property in China today is somewhat around $30 \%$, a level that seems to have stabilized since mid-2000s (Graph 6). This level is a bit higher but by no means incomparable to what it was in the West during the "golden age" of capitalism between 1950s to the 1980s. In the United States, Japan, France, German and Britain, the State owned between $15 \%$ and $25 \%$ of national wealth in the mid-1970s (Piketty, Li and Zucman, 2017, p. 22).

Graph 6: Share of Public Wealth in National Wealth, 1978-2015

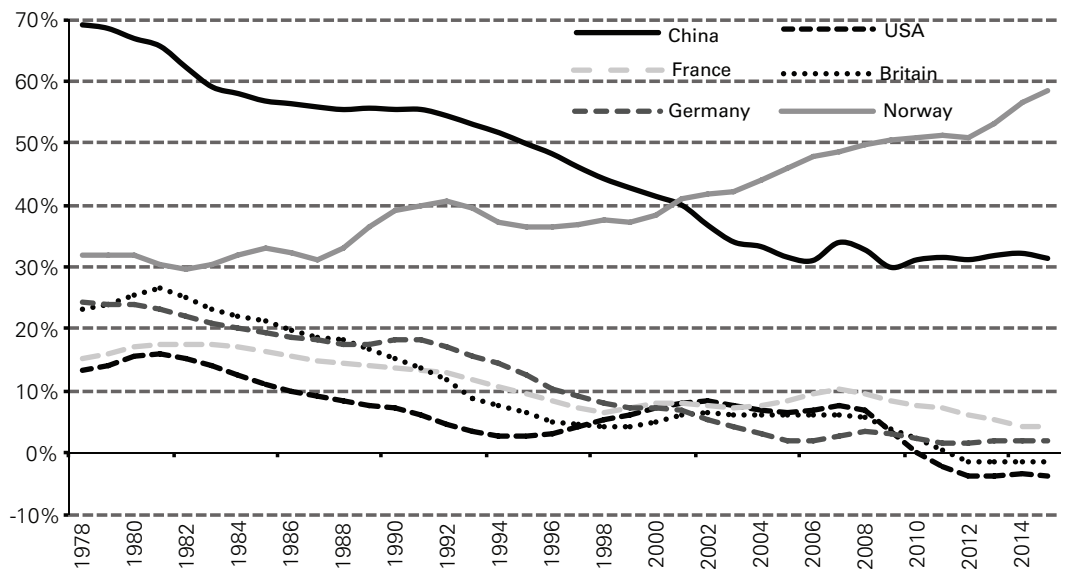

Source: World Wealth \& Income Database (WID.world).

Piketty, Li and Zucman (2017) have compared the evolution of the public share in China and in Norway, a developed country characterized by a large sovereign wealth fund due to its oil industry. They highlight that both countries have basically switched positions between 1978 and 2015: the public share in national wealth in China declined from $70 \%$ to $30 \%$, while in Norway it rose from $30 \%$ to 
$60 \%$ (Graph 6). A key difference, they note, is that in Norway public wealth is mostly invested abroad, which in the long run can be used to finance more public spending. In Norway, public property has mostly a fiscal and financial dimension used for social policies, not so much an industrial dimension (Piketty, Li and Zucman, 2017, p. 23).

In China, public property is in the key nodes for capital accumulation. China went through a rapid process of privatization of former public assets during its transition from a socialist planned economy to a State capitalist form. But privatization aimed at building a national "red capitalist" class linked to the State, and no public assets were sold to foreigners (Nogueira, 2018a). And most importantly, SOEs continued to have the "commanding heights" of Chinese industry (Lo and Wu, 2014). The Chinese State held on to its ability to affect the rate and direction of investment through its control of large-scale companies in steel, oil, petrochemicals, automobiles, rail, telecommunications and the banking system (Panitch and Gindin, 2013).

Since mid-1990s, Chinese SOEs have become mainly profit-oriented, nevertheless without abandoning the State's strategic dimension. In an economy characterized by a diversity of property structures (joint-ventures, private owned companies, limited liability, listed corporations etc.), large-scale SOEs and SOBs (State-Owned Banks) have been used as major economic agents in giving the shape and the pace of the accumulation strategy and in fostering technological upgrading. During the investment-led industrialization regime in the 2000s, for instance, public finance took the lead in massive infrastructural investment in upstream material industries. In this case, SOEs were key not only in defining the pace and direction of capital accumulation as major investors in rail, ports, pipelines, telecommunication lines, energy generation and transmission, but also in developing a world-frontier technology.

The role of State ownership for a successful national innovation system is a clear case in high-speed railway technology. China went very rapidly from an importer of world-frontier technology in high-speed trains (until 2004) to a worldleader competitor in the world-market (by 2011). Lo and Wu (2014, p. 321) argue that this was possible due to a combination of four factors that characterize China's innovation system: i. a State industrial policy based on the anticipation of an enormous national demand (between 2008 and 2011, China built up the largest network of high-speed rail in the world); ii. ample funding from Statecontrolled finance; iii. oligopolistic large-scale SOEs as the immediate carriers (China Northern Railways and China Southern Railways); iv. technology transfer deals assured by the national government when negotiating with transnational companies.

The impact of State ownership over distribution is huge. In contemporary China, this impact is not transmitted through employment anymore. Because public ownership is concentrated in capital-intensive sectors and totally absent in food 
production, textiles or garments, State ownership of industrial assets (39\% of total in 2014) is much larger than the State share of employment (18\%) (China Statistical Yearbook, 2015). Public ownership affects the regime of accumulation and how financialization evolves as argued in the previous section, and thus goes into the core of how the surplus is generated and distributed nationally. Besides its effects over the regime of accumulation, the size of State ownership also has fiscal consequences, as governments with large positive net public wealth can benefit from capital income and finance more spending and welfare transfers (Piketty, Li and Zucman, 2017; Lo and Wu, 2014).

The capacity of the State to promote regional development and to redistribute investment regionally through its commanding heights as public enterprises and banks became evident in the turn of the century. By then, the government launched three ambitious regional development programs that gained the nicknames of "Go West Policy", "Go Northeast" and "the Rising of Central China". The programs have two main engines for growth: aggressive investments in large-scale infrastructure (transport, energy generation and transmission and pipelines) and the promotion of industrial poles in the countryside. Their results have been successful as income per capita and GDP in inland provinces have been growing faster than coastal provinces since 2008 (Jabbour and Dantas, 2017; Nogueira, 2015). Clearly, SOEs investments are key parts of a national strategy to redistribute income and support poorer provinces.

\section{HOLDING INEQUALITIES BACK III: THE AGRARIAN QUESTION}

China's agrarian political economy - encompassing land structure, class formation, State interventions and the current dynamics of increasing capitalization of agriculture - has assumed very particular forms since reforms started in 1978 . The basic success of China's development path compared to India's or Latin America's in terms of the agrarian question has been avoiding a mass of landless or miserable rural population in the countryside. Instead, Chinese farming was distinctly established with marked small-scale and family-based features that contributed to sustain the fast economic growth and to achieving self-sufficiency in rice, wheat and corn - thus challenging modernization discourse in agriculture that only largescale farming works (Sheng, Song and Yi, 2017). Also, agricultural total factor productivity in China grew at an average of 3.1\% a year between 1978 and 2015, which is almost three times the global average of $1.3 \%$ and slightly higher than Brazil $(2.7 \%)$ in the same period, as graph 7 shows. 




Source: TFP calculated by the United States Department of Agriculture using FAO data.

This is not to say that the agrarian question in China has not manifested struggles, contradictions and ups and downs in labor-capital relations. In general terms, there have been three main periods for agrarian change that we will explore in this section. The first one, mainly during the 1980s, was the "golden age" for rural economy, when small plots were given to families, price policies along with public procurement programs assured high prices for producers and rural industrialization boosted rural employment. The second phase, from the 1990s until the beginning of the 2000s, is the "left-behind phase". It was marked by massive land expropriations, tax burdens onto farmers, privatization of rural enterprises, rural-urban income gap, and left behind families and children. It was then followed by the current third phase called "rural rejuvenation" or building a "new socialist countryside" by the CCP. It means State interventions and policies that help capital penetration in agriculture and, at the same time, reduces social conflicts through a comprehensive social package that started with the abolition of agricultural taxes and advanced through the building of a rural social welfare system (Zhang, Oya and Ye, 2015; Yan and Chen, 2015).

Going back to the "golden age", the major and first momentous change took place right away in the opening of the economic reforms, in 1978, with the dismantling of communes and the establishment of the Household Responsibility System (HRS). It meant land-use contracts of around 30 years and a fragmented land struc- 
ture of small plots of 0.73 hectare per family on average. In terms of property, land is still owned by local governments. From the point of view of its distribution, the HRS was impressively equitable, as there are no reports in the literature of relevant imbalances in land distribution in the initial decade of the reforms. In this sense, when communes were dissolved, egalitarian and universal distribution of land among rural population had become the main form of social protection that replaced the old communal system (Nogueira, 2018b).

Due to the rise of the bottom of the Chinese economic and social pyramid, the "golden age" was marked by aggressive reduction in extreme poverty and by a positive impact on the urban-rural gap. Alongside with the HRS, this period also registers an unprecedent upswing in agricultural prices resulting from a set of policies implemented by local and central governments that guaranteed high prices for agricultural products as well as the purchase of surplus grain that could not be sold in local markets. Between 1978 and 1983, prices for agricultural products rose $47.7 \%$ against a retail price index of $16.7 \%$, which implied a significant increase in real rural income - in this period, real urban income grew by $42.7 \%$, compared with $98.4 \%$ in rural areas (Nogueira, 2018b). Terms of trade favorable to agricultural goods and public procurement programs that assured that all grains produced would be bought by the government gave strong rise to peasants' income, thus contributing to closing the rural-urban gap and causing a significant impact in overall inequality in China.

Besides the new land structure and public procurement programs, the rural reform that has received the most attention and led to the most influential academic works is no doubt the amazing success of the Town-Village Enterprises (TVEs)-led rural industrialization. Between 1978 and 1996, TVEs went through a period of spectacular growth. By increasing the share of non-agricultural activities from $7.6 \%$ to $24.6 \%$ between $1978-1985$, TVEs raised rural income and absorbed workers from agriculture, thus, also playing a fundamental role in controlling inequality levels within China and in assuring that development would not be an exclusivity of the coastal areas (Nogueira, 2018b). It was a period of "triumphant" rural industrialization so rarely accomplished in other developing countries (Zhang, Oya and Ye, 2015, p. 300).

Nevertheless, the orientation of political and economic trends changed radically after Deng Xiaoping's famous Southern tour in 1992. There was a clear policy shift towards coastal areas and market reforms were accelerated. Price policies tended to prioritize urban residents and the urban-biased policies led to the exodus of the most educated portion of the labor force. The once-vibrant TVE sector "lost its luster under both increasing competition from urban firms and the burden of its own institutional constrains [...]. Abandoning farmland became widespread and agriculture output stagnated. But more importantly, this demographic change created a new set of social problems for rural China: the emergence of the 'left-behind' populations" (Zhang, Oya and Ye, 2015, p. 300-301). It meant that agriculture was an activity left behind for less educated people, the elderly and the children.

The demographic change provoked by poor conditions in rural areas and re- 
warding urban wage employment in cities was accompanied by what the literature calls as "the peasant burden": massive land expropriations coupled with excessive and arbitrary taxes imposed by local governments into agriculture and rural households as sources of fiscal revenue. China went through what Riskin (2008) called an "epidemic" of expropriation, fueled by both the expansion of the housing market (inflated by urbanization and speculation) and the fiscal needs of local governments. It is estimated that a total of 70 million farmers have lost their land by 2006 and have received "grossly inadequate" compensation (Nogueira, 2018a). They triggered widespread resentment among the rural population and gave rise to several violent political contentions (Bernstein and $\mathrm{Lu}$, 2003). This is the backdrop for the rise of the recent discourse that framed the whole rural atmosphere in China as "backward, unreformed and problematic". "The entire rural society appeared in the popular imagination and the national ideology of developmentalism and urbanism as something 'left behind' [...]. Rural society is constructed as a 'wasteland' inhabited by unproductive people, teeming with conflicts, and trapped in involution and stagnation" (Zhang, Oya and Ye, 2015, p. 301).

The answer to this chaotic picture came through building what the CCP calls as "the new socialist countryside": more social protection for rural residents and, at the same time, more State support for capitalist and market-based set of production relations. The discourse is united around "agriculture modernization" - agriculture larger in scale, with more technology and greater capital investments. And a set of policies has contributed to reduce urban-rural gap and to increase welfare in the bottom of the population. From 2004 to 2006, all agricultural taxes were completely abolished, eliminating one of the main sources of the "peasant burden". At the same time, a comprehensive rural social welfare system was built, including the New Cooperative Medical Scheme, the New Rural Social Pension Insurance and the Minimum Living Allowance (Zhang, Oya and Ye, 2015).

Agribusiness, for its turn, has opened a new frontier for capital accumulation. Even without a landlord class in contemporary China, Yan and Chen (2015) argue that there is a capitalist dynamic from above as urban-industrial or commercial capital engage in restructuring farming and modernizing agriculture. The most usual form of agribusiness penetration is through "dragon-head" enterprises that establish contract farming production networks with local farmers. To encourage land transfers and to accelerate land consolidation, in 2015 China's State Council amended the national Land Law by formally separating land operation rights from land contract rights. The directive, for the first time, allowed land contract rights to be legally transferred through market mechanisms (Sheng, Song and Yi, 2017).

In some cases, peasant farmers became wage laborers working for an agribusiness that now operates the land - either leasing their land or losing their land contract rights and thus becoming urban citizens. In other cases, rural households form a cooperative that is linked to an enterprise. Finally, there are cases that rural households turn their farmland into shares of an enterprise that operates on their 
land and gain dividends as their income. In sum, the aggregated numbers are impressive: by 2013 , there were 120,000 dragon-head enterprises linked with $40 \%$ of China's rural households, according to the Chinese Academy of Social Sciences (Yan and Chen, 2015).

The agrarian question in China has always been associated with a broader concern: the need for the strengthening of the nation. In this sense, the agrarian question must also be understood with respect to the agricultural challenges that China is facing in order to emerge as a powerful sovereign State - food security and power in the global agri-food chain. The top priority has shifted from ensuring grain self-sufficiency (rice, wheat, corn, soybean, root tubers) in the Maoist era to ensuring basic self-sufficiency in cereals (wheat, rice and corn) and control over global value chains.

Not by accident, the advance of agribusiness in rural China has been marked by continuous State intervention with the strategic purpose of giving the country the control over more sophisticate productive processes and over the global supply chain. The goal is to place Chinese companies among the top leader firms in agribusiness global value chains. The major step towards this direction was the recent acquisition of the Swiss-based giant Syngenta by the state-owned group ChemChina for US\$ 43 billion - the largest Chinese acquisition ever made abroad. Syngenta is world leader in advanced insecticides, herbicides, and other crop-protection products and the third largest producer of seeds. The transaction provides important insights on the relationship between the agrarian question on an international scale and the development of the nation: controlling the agri-food global value chains is a central issue to the Chinese leadership.

Such recent trend in agricultural production, nevertheless, does not clearly manifests itself in land concentration nationally. Surely, the demographic change, with people leaving the countryside and migrating to the urban parts of the country, alleviates the distributive impact of land consolidation. But most importantly, in most of the cases, land contract rights continue to be on peasant's names. In official statistics, the average size of farms in China in the early 1980s was 0.73 hectare, declining to 0.53 ha in 2003 and then rising moderately to 0.61 ha in $2013^{4}$ (Sheng, Song and Yi, 2017). The change in Chinese land contracts and uses in recent years has been a significant modification for Chinese agrarian pattern, but it shows an equitable access to land when comparing to international levels. To put it short, China's agrarian structure and its smallholding family farming, although changing throughout the whole period and going through several struggles, has been a crucial element in rising the base of the social pyramid. It has given China's distributional profile a more equitable face among middle income countries with a substantial portion of the population in rural areas.

\footnotetext{
${ }^{4}$ While in Brazil and the United States the average size of farms remained proportionally stable between 70 to 72 ha and 168 to 178 ha, respectively.
} 


\section{CONCLUSION}

Although inequalities grew fast in China since reforms started, certain modes of regulation in Chinese regime of accumulation have minimized the concentrating-tendency of capital and have kept inequalities in a moderate level on an international perspective. These modes of regulation are all very different from the neoliberal finance-led regime of accumulation under the US dollar that prevails globally and that is perceived as a major cause behind growing inequalities in most countries.

The financialization with Chinese characteristics is the first pillar of China's current regime of accumulation. It is defined by extensive capital controls, a mainly state-owned banking system, and administrated and low interest rates. Contrary to the finance-led regime under the US dollar, Chinese financialization has not displaced productive firms or jobs. In the same way, it did not come in order to compensate the fall of wages in national income through the indebtedness of families. And compared to countries like Brazil, financial markets and financial elites have not gained control over key State apparatus such as the Central Bank.

In the Chinese financial system, we may see a mix of Schumpeter with Minsky in the form of a robust entrepreneurial state. It is a State that combines two functions: that of a lender of last resort and of a first-tier investor. Having the banks at its core, the Chinese State can elaborate and finance industrial policies, technological innovations and infrastructure. It is a reinvigorated system of financial intermediation: a system which is made up of large State-controlled banks, closely linked to agriculture, commerce and, in particular, to industry, and oriented to financing the development process ${ }^{5}$.

The financialization with Chinese characteristics has been crucial to the State's arsenal for engineering and channeling its massive domestic investment and for giving birth to the so-called investment-led growth. One of its various distributional outcomes is to mitigate the "new working rich" phenomena that characterizes economies as the United States and the wealth and income concentration on the top $1 \%$. Its long-term goal is to foster the creation of an international monetary system less dependent on the dollar and based on multipolar institutions under Chinese control or influence. Not by accident, the financialization process in China has been essentially controlled by the State with intense control over the connections of the domestic financial system and international financial markets. Additionally, China is right now advancing on the constructions of international investment banks and infrastructure initiatives that mirror some of its national characteristics.

The second characteristic that distinguishes China from neoliberal finance-led regime is its large share of public ownership. A large share of public property affects the State's ability to conduct industrial and regional development policies and, there-

\footnotetext{
${ }^{5}$ We thank one of the referees for her/his insight on this.
} 
fore, directly strengthens the State's capacity to promote structural change. The share of public property in China was around 30\% in 2015, a level that has stabilized since mid-2000's (radically different from the United States or most of Europe, where public wealth in national wealth is virtually zero). The Chinese State held on its ability to affect the rate and direction of investment through its control of large-scale companies and through a national innovation system at the world-technology frontier. Public ownership goes into the core of how the surplus is generated and distributed. With the intension to redistribute the investment nationally, policies where taken forward by SOEs to expand their presence in the poorest West and Northeast regions. With a large share of State ownership, regional development policies with distributive goals become much more feasible. SOEs investments is clearly part of a strategy to redistribute income and support the poorer provinces.

Finally, China's agrarian political economy has assumed a much more egalitarian face if compared to other large countries such as Brazil, India or the United States. China's monumental success in reducing poverty in the 1980's was achieved through land reform, national public procurement programs and collective-led rural industrialization. Agricultural total factor productivity grew at an average of $2.86 \%$ a year between 1978 and 2013, which is more than three times the global average, and has led to self-sufficiency in basic-need cereals (rice, wheat and corn). This is to say that Chinese land structure, based on small-scale family farming, directly challenges modernization discourse in agriculture. Nevertheless, in the past decade, agribusiness and more capitalist set of production relations advanced fast in rural China through, for instance, "dragon-head" enterprises establishing contract farming production networks with local farmers. Agribusiness penetration in China has been marked by continuous State intervention with the strategic purpose of giving the country control over more sophisticated productive processes and over the global supply chain. The major step towards this direction was the acquisition of the Swiss-based giant Syngenta by a state-owned Chinese group - the largest Chinese acquisition ever made abroad. The negative distributive impact of such changes has been minimized through rural welfare policies that aim at building a "new socialist" countryside and through a land structure that continues to be extremely less concentrated on international comparisons.

The future prospects for Chinese inequalities will depend on how the struggles over financial liberalization and land concentration will evolve. These are arenas under intense dispute internationally and among Chinese capitalist fractions and the State. Their dynamics will not only shape China's national development but also the global dynamics of accumulation of capital and power.

\section{REFERENCES}

Aglietta, M. (1976). Règulation e crisis du capitalisme. Paris: Calmann-Lévy.

Aglietta, M. \& Bai, G. (2017). China's 13th Five-Year Plan. In Pursuit of a “Moderately Prosperous 
Society". CEPII Policy Brief No. 12, Paris: Centre d'Etudes Prospectives et d'Informations Internationales.

Alvaredo, F., Atkinson, A. B., Chancel, L., Piketty, T., Saez, E. \& Zucman, G. (2018). World Inequality Report 2018. Cambridge: Harvard University Press.

Bernstein, T. \& Lu, X. (2003). Taxation without Representation in Rural China: State Capacity, Peasant Resistance, and Democratization. Cambridge, UK: Cambridge University Press.

Boyer, R. (2010). "The Rise of CEO Pay and the Contemporary Social Structure of Accumulation in the United States”. In T. McDonough, M. Reich and D. Kotz (eds), Contemporary Capitalism and Its Crises: Social Structure of Accumulation Theory for the 21st Century, p. 215-38. New York: Cambridge University Press.

Bruno, M., Diawara, H., Araújo, E., Reis, A. C. \& Rubens, M. (2011). "Finance-led growth regime in Brazil". Brazilian Journal of Political Economy. V. 31, n. 5, p. 730-750.

Chen, L. (2017). “Containing capital outflows”. Ideas, Beijing: Gavekal Dragonomics.

Chesnais, F. (1994). La Mondialisation du Capital. Paris: Syros.

National Bureau of Statistics of China (2015). China Statistical Yearbook. Available at: <http://www. stats.gov.cn/english/statisticaldata/annualdata/> Last access in: March 7th 2018.

Cintra, M. A. \& Silva, E. B. (2015). "O sistema financeiro chinês: a grande muralha”. In: Cintra et al., China em Transformação: Dimensões Econômicas e Geopolíticas do Desenvolvimento. Brasília: IPEA.

Escobar, P. (2017). “China Plans to Break Petrodollar Stranglehold”. Asia Times, 21 de dezembro de 2017, available at: http://www.atimes.com/article/china-plans-break-petrodollar-stranglehold/. Last access in: 05/02/2018.

Huang, Y., Wang, X., Gou, Q. \& Wang, D. (2011). “Achieving capital account convertibility in China”. China Economic Journal, v. 4, n.1, p. 25-42.

Jabbour, E. \& Dantas, A. (2017). "The political economy of reforms and the present Chinese transition”. Brazilian Journal of Political Economy, v. 37, n. 4, p. 789-807.

Khan, A. R. \& Riskin, C. (2008). "Growth and distribution of household income in China between 1995 and 2002”. In B. Gustafsson, S. Li, and T. Sicular (eds.). Inequality and Public Policy in China, p. 1-34. New York, NY: Cambridge University Press.

Lapavitsas, C. (2009). "Financialised Capitalism: Crisis and Financial Expropriation”. Historical Materialism, v. 17, p. 114-148.

Li, S., Sato, H., \& Sicular, T. (2013). Rising inequality in China: challenges to a harmonious society. Cambridge: Cambridge University Press.

Lo, D. \& Wu, M. (2014). "The state and industrial policy in Chinese economic development". In: Salazar-Xirinachs, J. M., Nübler, I. \& Kozul-Wright, R., (eds.), Transforming Economies: Making industrial policy work for growth, jobs and development. Geneva: International Labour Office, $\mathrm{p}$. 307-326.

Medeiros, C. A. (2012). "Income concentration, financial liberalization, and the decoupling between the United States and China”. Journal of Economic Issues, v. 46, n. 2, p. 439-448.

Medeiros, C. A. \& Nogueira, I. (2011). “Uma análise estruturalista da distribuição de renda na China Contemporânea”. Revista Tempo do Mundo, v. 3, n. 3, p. 99-122.

Nogueira, I. (2018a). "Estado e capital em uma China com classes". Revista de Economia Contemporânea, v. 22, n. 1, p. 1-23.

Nogueira, I. (2018b). “A breve década de 80 e a questão agrária na reforma chinesa”. Texto para Discussão, Instituto de Economia da UFRJ.

Nogueira, I. (2015). "Desigualdades e políticas públicas na China: Investimentos, salários e riqueza na era da sociedade harmoniosa". In: Cintra, Silva e Pinto, eds. China em Transformação: Dimensões Econômicas e Geopolíticas do Desenvolvimento. Brasília: IPEA.

Panitch, L. \& Gindin, S. (2013). "The integration of China into global capitalism". International Critical Thought, v. 3, n. 2, p. 146-158.

Paulani, L. (2009). "The crisis of the finance-led regime of accumulation and the situation of Brazil". Estudos Avançados, v. 23, n. 66, p. 25-39. 
Piketty, T., Li, Y. \& Zucman, G. (2017). “Capital accumulation, private property and rising inequality in China”, 1978-2015. WID.world Working Paper 2017/6.

Pun, N. (2016). Migrant Labor in China. Cambridge: Polity Press.

Riskin, C. (2008). "Property rights and the social costs of transition and development in China". Economic and Political Weekly, v. 43, n. 52, p. 37-42.

Sheng, Y., Song, L. \& Yi, Q. (2017). "Mechanisation outsourcing and agricultural productivity for small farms: implications for rural land reform in China". In: Song et al. (eds.), China's New Sources of Economic Growth. Canberra: Australian National University Press, p. 289-313.

Vermeiren, M. \& Dierckx, S. (2012). "Challenging global neoliberalism? the global political economy of China's capital control”. Third World Quarterly, v. 33, p. 1647-1668.

Wang, Y. (2015). "The rise of the 'shareholding state': financialization of economic management in China”. Socio-Economic Review, v. 13, n. 3, p. 603-625.

WID.world. World Wealth and Income Database. Available at: http://wid.world/ Last access in February $2^{\text {nd }} 2018$.

Yan, H. \& Chen, Y. (2015). “Agrarian capitalization without capitalism? capitalist dynamics from above and below in China”. Journal of Agrarian Change, v. 15, n. 3, p. 366-391.

Zhang, Q., Oya, C. \& Ye, J. (2015). "Bringing Agriculture back in: the central place of agrarian change in rural China studies". Journal of Agrarian Change, v. 15, n. 3, p. 299-313. 